\title{
NUMERICAL AND ANALYTICAL SOLUTION OF THE PROBLEM ON DEFORMATION OF THE CIRCULAR CYLINDER USING THE BESSEL FUNCTIONS
}

\author{
Tetiana Shtefan; Andriy Zasovenko \\ Zaporizhzhya National Technical University, Ukraine
}

\begin{abstract}
Summary. The elastic deformation of the plate in the form of a circular cylinder under the action of a smooth stamp contacting with the plate along the entire surface of the upper base is considered. The work deals with the finding of the critical areas of a deformed circular cylinder, undergoing a constant axial deformation under the action of the compressive load. The top of the cylinder is pressed by a smooth, absolutely rigid parabolic stamp that moves vertically and contacts with the entire top of the cylinder. Lower base is free of loads. As a criterion of strength the Mises energy hypothesis is taken. The Eri function is represented in a trigonometric form using the Bessel functions of zero and first order. The analytical formulas for components of the stress tensor for the investigated body of rotation are obtained, as well as the function of the potential energy of the form-change in accordance with the Mises energy hypothesis. The adequacy of the constructed mathematical model is checked by the method of finite elements.
\end{abstract}

Key words: short cylinder, stamp, axisymmetric deformation, strength fourth hypothesis, Bessel functions.

Received 16.04.2018

Statement of the problem. The problems on the rotation bodies happen to be often solved during the engineering calculations. In such cases simplified equations of the elasticity theory are usually analyzed taking into account the symmetry of the bodies in question. Besides, the assumptions are introduced, at which these problems are treated as the most simple cases. But such an approach results in very sufficiently approximated solutions of the problems on finding the stresses and displacements in these bodies under deformations. To investigate the strength of the deformed bodies the hypothesis of strength are used, one of which is the energy (the fourth) hypothesis. The presented investigation deals with the finding of the critical areas of the body being deformed under rotation, the circular cylinder in particular, which is under the axisymmetric deformation, taking advantage of the energy strength hypothesis. The function of stresses is found as the trigonometric series, which makes possible to satisfy the conditions on the side surface of the cylinder [2].

Analysis of the latest investigations and publications. The multilayer cylinder-like structures are being widely used in the space, oil and gas engineering [3, 4]. The application of the relations of the spatial theory of elasticity to the study of such structures makes possible to obtain more reliable picture of the stress strain state. For example, in the papers $[4,5]$ the problem on the stress state of the loaded circular cylinder is solved taking advantage of the Fourier-Bessel series.

In the paper [6] the elastic cylinder of the finite length is analyzed taking into account its own weight, on the lower base of it the conditions of the smooth contact are provided, to the upper base of which the axisymmetric normal load is added and the side surface is the stressfree. The solution of the corresponding differential equation is constructed as the Fourier series due to the Jacobi polynom.

In the paper [7] the cylinder being in the axisymmetric stress state, which can be treated as one of the layer of cylindrical structure, is analyzed. Taking advantage of Bessel function the 
analytical solution of the problem on the cylinder stress has been obtained, which can be used while solving the problem on the stress-strain state of the multilayer cylindrical bodies.

The paper [8] is devoted to the theoretical investigations of the deformation damage under the axisymmetric deformation. The authors use the Mises criterion as the fracture criterion. The modeling is carried out by FEM using the structure ANSYS. The available results of the experimental investigations of the cylindrical blanks deformation by the stamp are presented in the paper [9].

The objective of the paper. The objective of the investigation in question is to identify the most dangerous areas of the circular cylinder being deformed by the stamp; to obtain the analytical expressions for the function specifying the structure strength according to the strength energy criterion; to find the most dangerous from the strength point of view areas of the deformed cylinder; to carry out the systematic analysis of the function behavior, which describes the potential energy of the form change. Numerical experiments have been carried out basing on the software package MAXIMA.

Statement of the task. The circular cylinder of $R$ radius and $l$ length, the axis of which coincides with the axis $O z$ and is under the axisymmetric deformation as it is in the [2], is analyzed. The cylindrical coordinates system $z, r, \theta$, originating in the middle of the layer base, is used. In this case $\tau_{r \theta}, \tau_{z \theta}$ are likely to be identically equal to zero, the other stress tensor components and the displacements vector do not depend on the angle $\theta$.

The top of the cylinder is pressed by a smooth absolutely rigid parabolic stamp, which moves vertically and contacts with the entire top base of the cylinder. The lower base is free of stresses. Similar to the [2] it will be considered, that on the side surfaces of the cylinder there are normal displacements, which equal zero as well as their derivatives along the vertical coordinate. The corresponding boundary conditions look like:

$$
\begin{gathered}
w(r, l)=f(r), \\
\tau_{r z}(r, 0)=0, \sigma_{z}(r, 0)=0, \\
w(R, z)=0 .
\end{gathered}
$$

It is considered, that $y=f(r)$ - is the equation of the line describing the stamp in the final position. Let us assume, that the function $f(r)$ is similar to the parabola $y=p(r-R)^{2} / R^{2}$, where $p$ - the maximum deflection of the top and $p=f(0)$

After finding the stresses bi-harmonic function $\varphi$ all non-zero components of the stress tensor and displacement tensor are found due to the formulas [10]:

$$
\begin{gathered}
\sigma_{r}=\frac{\partial}{\partial z}\left(v \nabla^{2} \varphi-\frac{\partial^{2} \varphi}{\partial r^{2}}\right) ; \quad \sigma_{\theta}=\frac{\partial}{\partial z}\left(v \nabla^{2} \varphi-\frac{1}{r} \frac{\partial \varphi}{\partial r}\right) \\
\sigma_{z}=\frac{\partial}{\partial z}\left((2-v) \nabla^{2} \varphi-\frac{\partial^{2} \varphi}{\partial z^{2}}\right) ; \quad \tau_{z r}=\frac{\partial}{\partial z}\left((1-v) \nabla^{2} \varphi-\frac{\partial^{2} \varphi}{\partial z^{2}}\right) ; \\
2 \mu u(r, z)=-\frac{\partial^{2} \varphi}{\partial r \partial z} ; \quad 2 \mu w(r, z)=2(1-v) \nabla^{2} \varphi-\frac{\partial^{2} \varphi}{\partial z^{2}} .
\end{gathered}
$$

Here it is marked $\nabla^{2}=\frac{\partial^{2}}{\partial r^{2}}+\frac{1}{r} \frac{\partial}{\partial r}+\frac{\partial^{2}}{\partial z^{2}}$. 
The precise solution of the stated problem is unknown. The approximate solutions for the cases of the long cylinder, short cylinder and "cubic" cylinder, the diameter and the height of which are the values of the same order, are built additionally [1].

Analytical solution of the problem. Let us use the solution for the long cylinder, in which the Bessel functions are applied. The function $\varphi(r, z)$ will be found as the trigonometric one due to the cosines (as it was done in the [11]). The function $\varphi(r, z)$ will be bi-harmonic, if

$$
\varphi(r, z)=\cos (k z)\left[b_{k} I_{0}(k r)+c_{k} k r I_{1}(k r)\right]
$$

where $I_{0}(k r), I_{1}(k r)$ - the generalized Bessel functions of the zero and first orders, correspondingly, and $b_{k}, c_{k}$ - the random constants.

The expressions (5), taking into account the expansions (6) for the displacement functions $u(r, z), w(r, z)$, will look like

$$
\begin{gathered}
2 \mu u(r, z)=\sin (k z)\left[c_{k} k r I_{0}(k r)+b_{k} I_{1}(k r)\right], \\
2 \mu w(r, z)=\cos (k z)\left[\left(\left(4 c_{k}(1-v)+b_{k}\right) I_{0}(k r)\right)+c_{k} k r I_{1}(k r)\right],
\end{gathered}
$$

and the components of the stress tensor according to the system (4) will look like:

$$
\begin{aligned}
& \sigma_{r}(r, z)=\frac{1}{r} k^{2} \sin (k z)\left[k r\left(c_{k}(1-2 v)+b_{k}\right) I_{0}(k r)+\left(c_{k} k^{2} r^{2}-b_{k}\right) I_{1}(k r)\right], \\
& \sigma_{\theta}(r, z)=\frac{1}{r} k^{2} \sin (k z)\left[k r c_{k}(1-2 v) I_{0}(k r)+b_{k} I_{1}(k r)\right], \\
& \sigma_{z}(r, z)=-k^{3} \sin (k z)\left[\left(2 c_{k}(2-v)+b_{k}\right) I_{0}(k r)+c_{k} k r I_{1}(k r)\right], \\
& \tau_{r z}(r, z)=-k^{3} \sin (k z)\left[\left(2 c_{k}(1-v)+b_{k}\right) I_{0}(k r)+c_{k} k r I_{1}(k r)\right] .
\end{aligned}
$$

Further let us be limited only by the same $k=1$ and substitute the obtained expressions in the boundary conditions. The conditions (2) are satisfied identically:

$$
\begin{aligned}
& \sigma_{z}(r, 0)=-\sin 0 \cdot\left[\left(2 c_{1}(2-v)+b_{1}\right) I_{0}(r)+c_{1} r I_{1}(r)\right] \equiv 0, \\
& \tau_{r z}(r, 0)=-\sin 0 \cdot\left[\left(2 c_{1}(1-v)+b_{1}\right) I_{0}(r)+c_{1} r I_{1}(r)\right] \equiv 0 .
\end{aligned}
$$

The condition (3)

$$
2 \mu w(R, z)=\cos z \cdot\left[\left(4 c_{1}(1-v)+b_{1}\right) I_{0}(R)+c_{1} R I_{1}(R)\right]=0,
$$

will be satisfied, if the random constants are connected by the relation

$$
b_{1}=c_{1}\left(4(v-1)-R \frac{I_{1}(R)}{I_{0}(R)}\right)
$$

from the condition (1) we will obtain the equation

$$
2 \mu w(r, l)=\cos l \cdot\left[\left(4 c_{1}(1-v)+b_{1}\right) I_{0}(r)+c_{1} r I_{1}(r)\right]=2 \mu f(r) .
$$


From here we will write the function $f(r)$, which will describe the shape of the stamp surface:

$$
f(r)=\frac{c_{1}}{2 \mu} \cos l \cdot\left[r I_{1}(r)-R \frac{I_{1}(R)}{I_{0}(R)} I_{0}(r)\right],
$$

the graph of the function $f(r)$ at $R=1, \mu=0.5, c_{1}=1$ is presented in Fig. 1 .

As it is seen in the figure the surface of the stamp is similar to that parabolic one. The value of the constant $c_{1}$ will be found from the equality of the maximal deflection of the value $p$

$$
p=f(0)=-\frac{c_{1}}{2 \mu} \cos l \cdot R \frac{I_{1}(R)}{I_{0}(R)}
$$

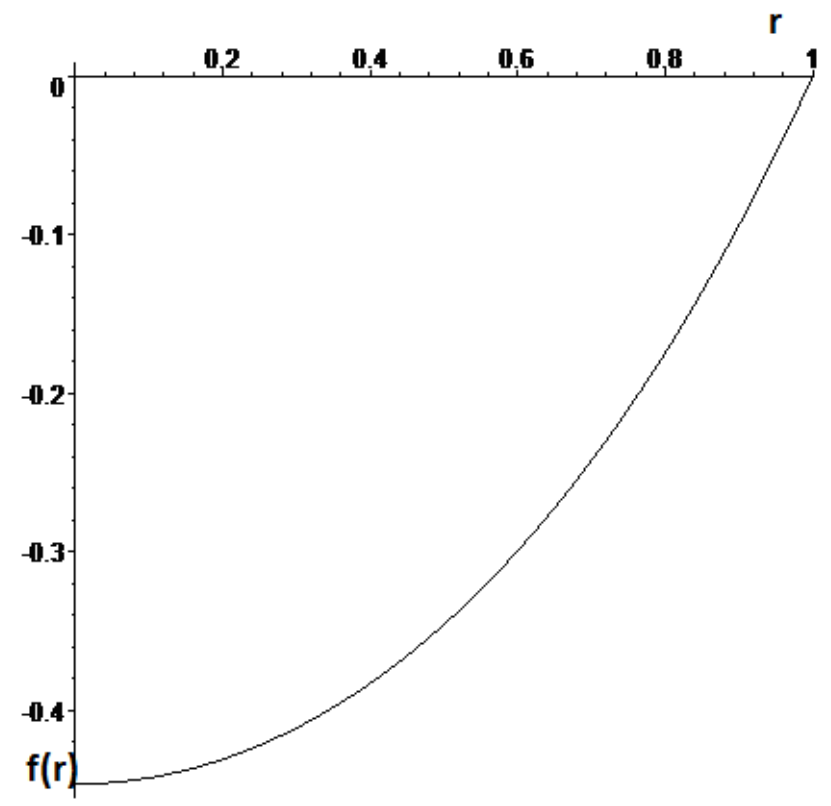

Figure 1. Form of the surface of the stamp $f(r)$

from here it follows, that

$$
\left\{\begin{array}{l}
c_{1}=-\frac{2 \mu \cdot f(0)}{\cos l} \cdot\left[\frac{I_{0}(R)}{R I_{1}(R)}\right] \\
b_{1}=\frac{2 \mu \cdot f(0)}{\cos l} \cdot\left[\frac{4(1-v) I_{0}(R)+R I_{1}(R)}{R I_{1}(R)}\right] .
\end{array}\right.
$$

As the values of the random constants have been calculated, all components of the displacements vector (7) - (8) and stresses tensor (9) of the axisymmetric deformation of the circular cylinder can be found. 
The results of investigation the function of the form change potential energy.

The energy theory of strength is based on the assumption, that the amount of the form change potential energy, accumulated till the ultimate state of the material is reached, is similar to that both under the complex stress state and under the simple uniaxial tension. If the strength condition due to the Mises energy hypothesis [10] is presented as the components of the stresses tensor in the cylindrical system of coordinate, taking into account the fact, that the components $\tau_{r \theta}, \tau_{z \theta}$ equal zero identically, we will obtain the function of the potential energy similar to that in the [11], which will look like:

$$
\sigma^{\mathrm{II}}=F(x, y, z)=\sqrt{\left(\sigma_{r}+\sigma_{\theta}+\sigma_{z}\right)^{2}-3\left(\sigma_{r} \sigma_{\theta}+\sigma_{r} \sigma_{z}+\sigma_{\theta} \sigma_{z}-\tau_{r z}^{2}\right)}
$$

As all the components of the stresses tensor (9) can be written in the real appearance

$$
\begin{aligned}
& \sigma_{r}(r, z)=\frac{1}{r} \sin (z)\left[r\left(c_{1}(1-2 v)+b_{1}\right) I_{0}(r)+\left(c_{1} r^{2}-b_{1}\right) I_{1}(r)\right], \\
& \sigma_{\theta}(r, z)=\frac{1}{r} \sin (z)\left[r c_{1}(1-2 v) I_{0}(r)+b_{1} I_{1}(r)\right] \\
& \sigma_{z}(r, z)=-\sin (z)\left[\left(2 c_{1}(2-v)+b_{1}\right) I_{0}(r)+c_{1} r I_{1}(r)\right] \\
& \tau_{r z}(r, z)=-\sin (z)\left[\left(2 c_{1}(1-v)+b_{1}\right) I_{0}(r)+c_{1} r I_{1}(r)\right]
\end{aligned}
$$

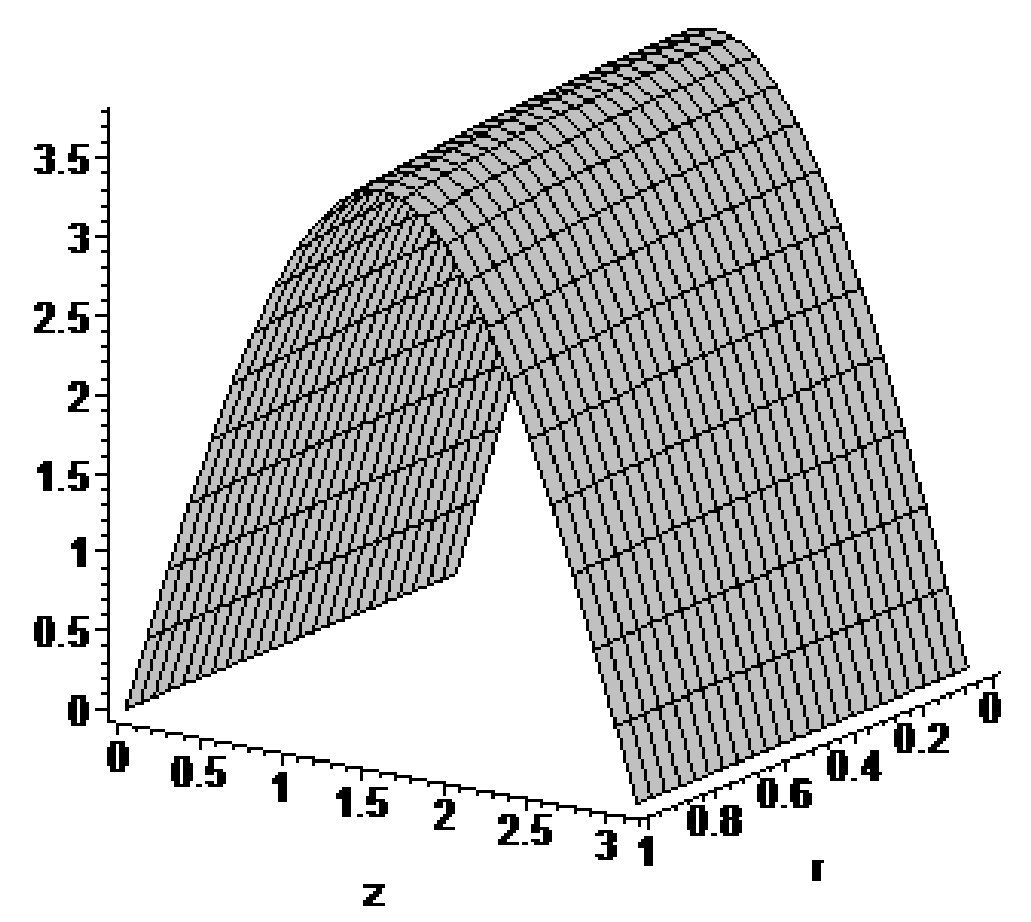

Figure 2. Graph of the potential energy function at $R=1, \mu=0.5, c_{1}=1$ 


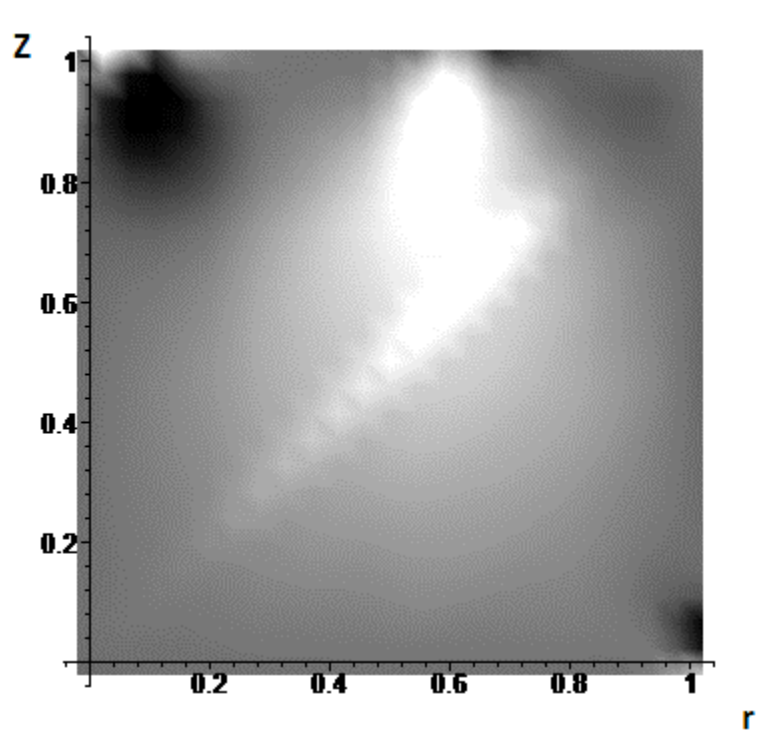

a)

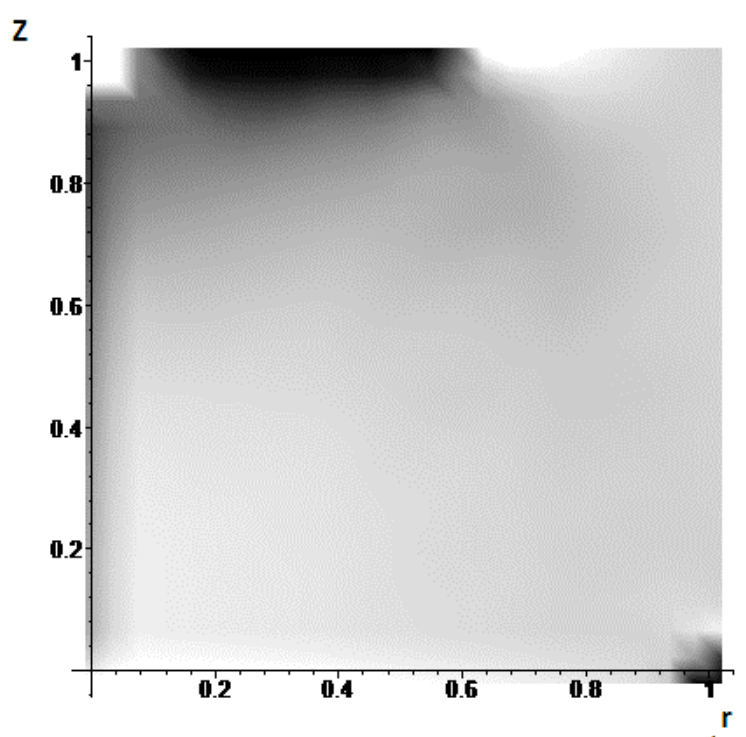

b)

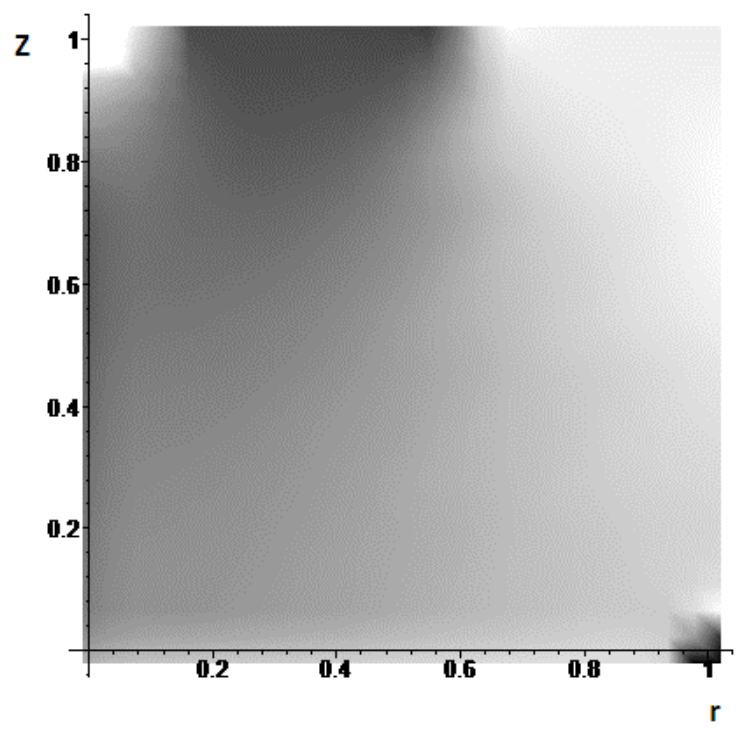

c)

Figure 3. Distribution of stress tensor components: a) density of the cylinder's stresses $\sigma(r, z)$;

b) density of the cylinder's stresses $\sigma(r, r)$; c) density of the cylinder's stresses $\sigma(z, z)$

Here the constants are specified by the expressions (12) and the Bessel functions are specified by the tables, then the function of the potential energy has been found.

Let us analyze the numerical problem: The equation of the lower surface of the stamp in the final position is considered to be described by the function

$$
f(r)=\frac{c_{1}}{2 \mu} \cos l \cdot\left[r I_{1}(r)-R \frac{I_{1}(R)}{I_{0}(R)} I_{0}(r)\right]
$$

the values of the random constants correspond to the expressions (12). In Fig. 2 the graph of the function of the potential energy (13) at the values of the stamp parameters $R=1, \mu=0.5, c_{1}=1$ is presented. 
The reliability of the constructed mathematic model will be checked by the method of the finite elements, having plotted the sizes of the area net pegging-out $50 \times 50$. In Fig. 3 the distribution of the stress tensor components is presented

Conclusions. A circular cylinder being under axisymmetric deformation was analyzed. The coefficients of the expansion of the Eri stresses function in a trigonometric series over cosines with the use of the Bessel functions of zero and first order were found. The analytical developments of components of the displacement vector and the stress tensor in the axisymmetric deformation of the circular cylinder were determined, as well as the function of the potential energy of the form-change in accordance with the Mises energy hypothesis. The most dangerous in terms of the strength of the area of the circular cylinder are identified. The reliability of the constructed mathematical model is checked by the method of finite elements. In the future it is planned to carry out a detailed numerical analysis of the positions of maximum stresses while deforming simultaneously both of the cylinder bases. The obtained results are also planned to be generalized in the case of multilayer cylinders made of various materials used, for example, in the gas industry.

\section{References}

1. Timoshenko S. Kurs teorii uprugosti. Kiev, Naukova dumka, 1972, p. 508 [In Ukrainian].

2. Shtefan T.A., Velichко H.V. Energiya formoizmeneniya in korotkom zilindre pri aksialnoy simmetricheskoy deformazii. Derormaziya i razrushenie materialov. Moscow, 2014, no. 6, pp. 12 - 18 [In Russian]

3. Bekaev A.E. Ob odnoy zadache mnogosloynogo zilindra. Izvestiya RAN RK. Seriya fizikomatematicheskaya. Almatu, 2012, no. 1(281), pp. 39 - 43 [In Russian].

4. Olegin I.P. Opredelenie napryazhzhenogo sostoyaniya v transversalno-izotropnuh zilindricheskih telah. Nauchnuy vestnik NGTU. 2001, no. 2, pp. 95 - 104 [In Russian].

5. Vigak V.M., Tokoviy U.N. Tochnuy rozvazok osesimetrichnoyi zadachi teorii pruzhnosti v napruzhenyah dlya suzilnogo zilindra pevnoyi dovzhini. Prikladni problemi mechaniki i matematiki. 2003, no. 1, pp. 55 -60 .

6. Chan K.T.,Wei X.X. A new analytic solution for the diametral point load strength test on finite solid circular cylinders. International journal of solids and structures. 2001, vol. 38, no. 4, pp. $1459-1481$.

7. Prozerov U.S. Osesimmetrichnie zadachi teorii uprugosti dlya zilindra konechnoyi dlini so svobodnoy zilindricheskoy poverhnostiyu i uchetom sobstvennogo vesa. Vestnik nazionalnogo universitetu. Matematika i mechanika. 2013, vol.18, no. 3 (19), pp. 69 - 81 [In Russian].

8. Kuchar V.V. Makropokazateli formoizmeneniya i rabota defofmazii pri osadke zagotovok vupuklimi plitami. Visnik nazionalnogo tehnicheskogo universitetu Ukraini "KPI". Seriya "Mashinobuduvannya". Kiev, 2012, no. 64, pp. 227 - 233 [In Russian].

9. Tutishkin N.D., Kuang H.H. Modelirovanie deformazionnoy povrezhdaemosti materialov pri osesimmetricheskoy osadke. Izvestiya TulGU. Estestvenniye nauki. Tula, 2011, no. 1, pp. 129 - 137 [In Russian].

10. Vlasov V.Z., Leontiev N.N. Balki, pliti I oolochki na uprugom osnovanii. Moskva, 1960, p. 490 [In Russian].

11. Shtefan T.A., Velichко H.V. Chislenno-analiticheskoe reshenie zadachi ob osesimmetricheskoy deformazii $\mathrm{v}$ cilindre pod deystviem szimauschih nagruzok. Mehanika mashin, mehanizmov I materialov. Minsk, 2017, no. 4(41), pp. 89 - 95 [In Russian].

\section{Список використаної літератури}

1. Тимошенко, С.П. Курс теории упру гости [Текст] /С.П. Тимошенко. - Киев : Наукова думка, 1972. $-508 \mathrm{c}$.

2. Штефан, Т.А. Энергия формоизменения в коротком цилиндре при аксиальной симметрической деформации [Текст] / Т.А. Штефан, Е.В. Величко // Деформация и разрушение материалов. -2014. - № 6. - С. $12-18$.

3. Бекаев, А.Е. Об одной задаче многослойного цилиндра [Текст] / А.Е. Бекаев // Известия НАН РК. Серия физико-математическая. - № 1 (281). - Алматы, 2012. - С. 39 - 43.

4. Олегин, И.П. Определение напряженного состояния в трансверсально-изотропных цилиндрических телах [Текст] / И.П. Олегин // Научный вестник НГТУ. - 2001. - № 2. - С. 95 104. 
5. Вігак, В.М. Точний розв’язок осесиметричної задачі теорії пружності в напруженнях для суцільного циліндра певної довжини [Текст] / В.М. Вігак, Ю.В. Токовий // Прикладні проблеми механіки і математики. - 2003. - Вип. 1. - С. 55 - 60 .

6. Chan, K.T. A new analytic solution for the diametral point load strength test on finite solid circular cylinders [Text] / K.T. Chan, X. X. Wei // International journal of solids and structures. - 2001. - Vol. 38, № 4. - P. $1459-1481$.

7. Процеров, Ю.С. Осесимметричные задачи теории упругости для цилиндра конечной длины со свободной цилиндрической поверхностью и учетом собственного веса [Текст] / Ю.С. Процеров // Вісник Од. нац. ун-ту. Мат. і мех. - 2013 .- Т. 18, Вип. 3 (19). - С. 69 - 81.

8. Кухарь, В.В. Макропоказатели формоизменения и работа деформации при осадке заготовок выпуклыми плитами [Текст] / В.В. Кухарь // Вісник Національного технічного університету України «КПІ». Серія «Машинобудування». - Київ : Вип. № 64, 2012. - С. 227 - 233.

9. Тутышкин, Н.Д. Моделирование деформационной повреждаемости материалов при осесимметричной осадке [Текст] / Н.Д. Тутышкин, Х.Х. Куанг // Известия ТулГУ. Естественные науки. - Тула : Вып. № 1, 2011. - С. 129 - 137.

10. Власов, В.З. Балки, плиты и оболочки на упругом основании [Текст] / В.З. Власов, Н.Н. Леонтьев. Москва : ГИФМЛ, 1960. - 490 с.

11.Штефан, Т.А. Численно-аналитическое решение задачи об осесимметрической деформации в цилиндре под действием сжимающих загрузок [Текст] / Т.А. Штефан, Е.В. Величко // ISSN 199550470 Механика машин, механизмов и материалов. - Минск, респ. Беларусь. - 2017. - № 4 (41). - C. $89-95$.

\title{
УДК 539.313
}

\section{ЧИСЕЛЬНО-АНАЛІТИЧНИЙ РОЗВ'ЯЗОК ЗАДАЧІ ПРО ДЕФОРМАЦІЮ КРУГОВОГО ЦИЛІНДРА 3 ВИКОРИСТАННЯМ ФУНКЦЙ БЕССЕЛЯ}

\author{
Тетяна Штефан; Андрій Засовенко
}

\section{Запорізький начіональний технічний університет, Запоріжжя, Україна}

Резюме. Розглянуто пружну деформацію пластини у вигляді кругового циліндра під дією гладкої мембрани, яка контактує з пластиною вздовж усієї поверхні верхньої основи. Робота проводиться в напрямку знаходження критичних ділянок деформованого кругового ичиліндра, щзо знаходиться в постійній осьовій деформації під дією стискуючого навантаження. Верхівка ичиліндра натискається гладкою, абсолютно жорсткою параболічною печаткою, яка рухається вертикально і контактує з усією верхньою частиною циліндра. Нижня основа вільна від навантажень. Вважсається, щуо у $=f(r)$ - рівняння лінії, яка описує штамп у кінцевій позиції. Також вважається, щзо функція $y=f(r)$ близька до параболи $y=p(r-R)^{2} / R^{2}$, де $p$ - максимальний прогин верхньої основи та $p=y(0)$. Як критерій міцності застосовується енергетична гіпотеза Мізеса. Функиія Ері представлена в тригонометричній формі за допомогою функиій Бесселя нульового та першого порядку $\varphi(r, z)=\cos (k z)\left[b_{k} I_{0}(k r)+c_{k} k r I_{1}(k r)\right]$. Отримано аналітичні формули для компонент тензора напружень досліджуваного тіла обертання, а також функиія потенціальної енергї формозміни відповідно до енергетичної гіпотези Мізеса. Під час чисельного розв'язку задачі ми вважатимемо, щэо рівняння нижньої поверхні штампа в кінцевому положенні описується функиією $f(r)=\frac{c_{1}}{2 \mu} \cos l \cdot\left[r I_{1}(r)-R \frac{I_{1}(R)}{I_{0}(R)} I_{0}(r)\right]$ зі значеннями параметрів штампа $R=1, c_{1}=1$. Коефіиієнт Пуассона дорівнює 0,25, модуль зсуву - 0,5. Чисельно знайдено найнебезпечніші з точки зору міцності області кругового ичиліндра. Адекватність побудованої математичної моделі перевіряється методом скінчених елементів. Представлені в статті графіки функиії потенціальної енергії формозміни вказують на небезпечні з точки зору міцності ділянки кругового циліндра. Отримані результати планується узагальнити у випадку багатошарових циліндрів, виготовлених з різних матеріалів, які часто використовуються в промисловості.

Ключові слова: короткий ичиліндр, штамп, осесиметрична деформація, енергетична гіпотеза Мізеса, функиії Бесселя. 